\title{
Plasmid Analysis and Cloning of the Dichloromethane-utilization Genes of Methylobacterium sp. DM4
}

\author{
By RENÉ GÄLLI† AND THOMAS LEISINGER* \\ Mikrobiologisches Institut, Eidgenössische Technische Hochschule Zürich, CH-8092 Zürich, \\ Switzerland
}

(Received 21 October 1987; revised 11 December 1987)

\begin{abstract}
The dichloromethane (DCM)-utilizing facultative methylotroph Methylobacterium sp. DM4 was shown to contain three plasmids with approximate sizes of $120 \mathrm{~kb}, 40 \mathrm{~kb}$ and $8 \mathrm{~kb}$. Curing experiments suggested that the DCM-utilization character was correlated with the possession of an intact $120 \mathrm{~kb}$ plasmid. The DCM-utilization genes were cloned on the broad-host-range vector $\mathrm{pVK} 100$. Plasmid pME1510, a recombinant plasmid carrying a $21 \mathrm{~kb}$ HindIII fragment complemented DCM-utilization-negative derivatives of Methylobacterium sp. DM4 and conferred the DCM-utilization-positive phenotype to a number of Gram-negative methylotrophic bacteria. In Southern hybridization experiments with pME1510 as a probe, chromosomal DNA from Methylobacterium sp. DM4 gave definite signals while purified plasmid DNA did not. Plasmid pME1510 did not hybridize with total DNA from a cured DCMnon-utilizing derivative of Methylobacterium sp. DM4. It is concluded that the DCM-utilization genes are located on the chromosome or on a megaplasmid. Curing procedures thus led to the formation of a chromosomal or megaplasmid deletion larger than $21 \mathrm{~kb}$ and covering the DCMutilization genes or to the loss of an undetected megaplasmid.
\end{abstract}

\section{INTRODUCTION}

Soil bacteria isolated after enrichment for growth on dichloromethane (DCM) as the sole carbon and energy source have been shown to comprise facultative methylotrophs of the genera Pseudomonas (Brunner et al., 1980; Gälli \& Leisinger, 1985; LaPat-Polasko et al., 1984) and Hyphomicrobium (Stucki et al., 1981). Some of the DCM-utilizing Pseudomonas isolates are pinkpigmented facultatively methylotrophic bacteria which, according to a recent taxonomic study (Green \& Bousfield, 1983), should be placed in the genus Methylobacterium. This is the case for Methylobacterium sp. strain DM4 which is the subject of the present communication and formerly was named Pseudomonas sp. DM4 (Gälli \& Leisinger, 1985; Kohler-Staub et al., 1986). The ability to grow on DCM depends on the possession of DCM dehalogenase. This enzyme, a hexamer with a subunit $M_{\mathrm{r}}$ of approximately 33000 , requires reduced glutathione as a cofactor and converts one molecule of DCM into one molecule of formaldehyde and two molecules of hydrochloric acid. It is highly inducible by its substrate and constitutes about $16 \%$ of the total soluble protein of induced cells (Kohler-Staub \& Leisinger, 1985).

The purified DCM dehalogenases of two Hyphomicrobium strains, one Pseudomonas sp., and of Methylobacterium sp. DM4 have recently been compared. They were immunologically similar, exhibited the same subunit $M_{\mathrm{r}}$ and were identical with respect to the $15 \mathrm{~N}$-terminal amino acids (Kohler-Staub et al., 1986). These observations suggested that the DCM dehalogenase structural gene and a putative regulatory gene were horizontally distributed among facultatively methylotrophic bacteria. In the present communication we describe the

$\dagger$ Present address: Department of Civil Engineering, Stanford University, Stanford, CA 94305, USA.

Abbreviations: DCM, dichloromethane; Tc, tetracycline; Km, kanamycin; Sm, streptomycin.

0001-4485 (C) 1988 SGM 


\section{Table 1. Bacterial strains and plasmids}

Genetic symbols for $E$. coli strains are standard. Dcm ${ }^{+}$, DCM-utilization-positive phenotype; PPFM, pink-pigmented, facultatively methylotrophic bacterium.
Strain or plasmid
Genotype or relevant properties
Source or reference

E. coli
HB101
LE392
BHB2688
BHB2690

Protaminobacter ruber

(ATCC 8457)

Pseudomonas extorquens

(DSM 1337)

Pseudomonas sp. M27

(DSM 1339)

Methylobacterium organophilum XX

(ATCC 27886)

Methylobacterium sp.

DM4

DM4-2c

DM4-2cr

DM4-161

DM4-161c

AMl(ATCC1478)

AM1r

Plasmids

pVK 100

pRK2013

pME1510

pME1511

pME1512

pME1513

pME1514

pME1515
$\mathrm{F}^{-}$pro leu hsdR hsdM recA supE rpsL $\left(\mathrm{Sm}^{\mathrm{r}}\right)$

$\mathrm{F}^{-}$met hsdR hsdM supE supF

$\mathrm{N} 205 \mathrm{rec} A\left(\lambda \mathrm{imm}^{434} \mathrm{cIts}\right.$ b2 red Eam Sam/ $\left.\lambda\right)$

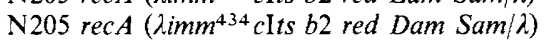

$\mathrm{Dcm}^{-}$, PPFM

$\mathrm{Dcm}^{-}$, PPFM

$\mathrm{Dcm}^{-}, \mathrm{PPFM}$

$\mathrm{Dcm}^{-}$, PPFM

$\mathrm{Dcm}^{+}$, PPFM (pME1511, pME1512, pME1513)

$\mathrm{Dcm}^{-}$(pME1512, pME1513)

$\mathrm{Dcm}^{-} \mathrm{Sm}^{\mathrm{s}}$ (pME1512, pME1513)

$\mathrm{Dcm}^{+}(\mathrm{pME} 1511, \mathrm{pME} 1512)$

$\mathrm{Dcm}^{-}$(pME1514)

$\mathrm{Dcm}^{-}, \mathrm{PPFM}$

$\mathrm{Dcm}^{-}$Rif

$\mathrm{Km}^{\mathrm{r}} \mathrm{Tc}^{\mathrm{r}}$, mobilizable cloning vector derived from RK2 containing the cohesive ends of the phage $\lambda$

$\mathrm{Km}^{\mathrm{r}}$, self-transmissible derivative of $\mathrm{RK} 2$ containing ColEl replicon and transfer functions necessary to mobilize pVK 100 and its derivatives

$\mathrm{Tc}^{r} \mathrm{Dcm}^{+}$recombinant plasmid of $\mathrm{pVK} 100$ containing a $21 \mathrm{~kb}$ HindIII fragment from DM4

$120 \mathrm{~kb}$ cryptic plasmid of DM4

$40 \mathrm{~kb}$ cryptic plasmid of DM4

$8 \mathrm{~kb}$ cryptic plasmid of DM4

$50 \mathrm{~kb}$ cryptic plasmid of DM4-161 c

$\mathrm{Km}^{\mathrm{r}}$ recombinant plasmid of pVK 100 containing a $7 \mathrm{~kb}$ SalI fragment of pME1511
Boyer \& Roulland-Russoix (1969)

Maniatis et al. (1982)

Hohn (1973)

\{

Green \& Bousfield (1982)

Gälli \& Leisinger (1985)

Cured derivative of DM4, this study

$\mathrm{Sm}^{r}$ derivative of DM4-2c, this study

Spontaneous derivative of

DM4, this study

Cured derivative of

DM4-161, this study

Green \& Bousfield (1982),

Peel \& Quayle (1961)

Rif derivative of AM1, this study

Knauf \& Nester (1982)

Figurski \& Helinski (1979)

This study

cloning of the DCM-utilization genes of Methylobacterium sp. DM4 and their expression in DCM-non-utilizing facultative methylotrophs. We also present evidence that these genes are not located on any of the three plasmids we have detected in Methylobacterium sp. DM4.

\section{METHODS}

Bacterial strains, plasmids and culture conditions. The bacteria and plasmids used in this study are listed in Table 1. Escherichia coli strains were grown at $37^{\circ} \mathrm{C}$ on LB medium (Maniatis et al., 1982).

Methylobacterium sp. DM4 was grown at $30^{\circ} \mathrm{C}$ in batch cultures on a rotary shaker with methanol or DCM as the carbon and energy source. The minimal medium used and the cultivation on the toxic and volatile substrate DCM have been described elsewhere (Kohler-Staub et al., 1986). Methylamine agar contained $\left(1^{-1}\right) 0.68 \mathrm{~g}$ 
$\mathrm{CH}_{3} \mathrm{NH}_{2}, \mathrm{HCl}, 1.36 \mathrm{~g} \mathrm{KH}_{2} \mathrm{PO}_{4}, 1.78 \mathrm{~g} \mathrm{Na}_{2} \mathrm{HPO}_{4} .2 \mathrm{H}_{2} \mathrm{O}, 0.2 \mathrm{~g}\left(\mathrm{NH}_{4}\right)_{2} \mathrm{SO}_{4}, 0.1 \mathrm{~g} \mathrm{MgSO} \mathrm{Mg}_{4} .7 \mathrm{H}_{2} \mathrm{O}$ and $15 \mathrm{~g}$ agar. $\mathrm{DCM}$ indicator agar was used for selection and detection of DCM degrading recombinant clones; it contained

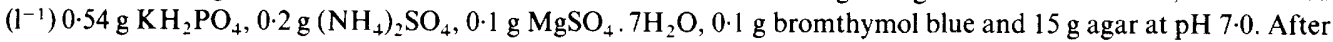
sterilization of the solid media described above, trace elements were added as described by Stucki et al. (1981). The DCM indicator plates were incubated in a desiccator whose atmosphere contained DCM. The optimum DCM concentration in the air of the closed container was obtained by including a reagent tube with $0.1 \mathrm{ml} \mathrm{DCM}$ per litre of air volume. Bacterial degradation of DCM was accompanied by the release of hydrochloric acid which led to a zone of colour change from dark-green to yellow around degradative colonies.

Antibiotic concentrations $\left(\mathrm{ml}^{-1}\right)$ were $25 \mu \mathrm{g}$ for tetracycline $(\mathrm{Tc}), 50 \mu \mathrm{g}$ for kanamycin sulphate $(\mathrm{Km})$, and $200 \mu \mathrm{g}$ for streptomycin sulphate $(\mathrm{Sm})$ and rifamycin (Rif).

Isolation of antibiotic-resistant mutants of Methylobacterium sp. DM4. Nutrient agar plates containing $20 \mu \mathrm{g}$ Rif or $\mathrm{Sm} \mathrm{ml} \mathrm{m}^{-1}$ were inoculated with $10^{9}$ bacteria from liquid cultures. After 6 to $10 \mathrm{~d}$ incubation, resistant colonies were picked and streaked on nutrient agar plates with increased antibiotic concentrations. This procedure was repeated several times and led to strains resistant to $200 \mu \mathrm{g} \mathrm{Rif} \mathrm{ml}^{-1}$ or $500 \mu \mathrm{g} \mathrm{Sm} \mathrm{ml} \mathrm{g}^{-1}$, corresponding to a 10-fold and 100fold increase, respectively, in the MIC.

Curing experiments. Methylobacterium sp. DM4 was grown for 20 generations in liquid minimal medium with either $10 \mathrm{~mm}$-methanol or $10 \mathrm{~mm}$-succinate (sodium salt) as the sole carbon and energy source. To obtain $\mathrm{Dcm}^{-}$ mutants the cells were either incubated at the maximum growth temperature of $32{ }^{\circ} \mathrm{C}$ or at $30^{\circ} \mathrm{C}$ in the presence of $1 \mu \mathrm{g}$ mitomycin $\mathrm{C} \mathrm{ml}^{-1}$. Samples of the grown cultures were plated on methylamine agar. After 6 to $8 \mathrm{~d}$ incubation, single colonies were picked and transferred to methylamine plates and DCM indicator plates to give the proportion of $\mathrm{Dcm}^{-}$derivatives.

Isolation and manipulation of DNA. Preparative amounts of plasmid DNA were isolated from Escherichia coli $\mathrm{HB} 101$ by the method of Itoh et al. (1984). For analytical purposes, cosmids were isolated from $E$. coli HB101 by the alkaline lysis method described by Maniatis et al. (1982). Total cellular DNA from Pseudomonas aeruginosa PAOI and Methylobacterium sp. strains was purified by the method of Chesney et al. (1979).

Methylobacterium sp. plasmid DNA was isolated essentially by the method of Kado \& Liu (1981). Methanolgrown cells (1 l) were harvested by centrifugation $(5200 \mathrm{~g}, 20 \mathrm{~min})$ and washed twice with saline $(0 \cdot 85 \%, \mathrm{NaCl})$. The pellet was resuspended in $20 \mathrm{ml}$ E-buffer ( $40 \mathrm{~mm}$-Tris/ $\mathrm{HCl}, 2 \mathrm{~mm}$-EDTA, pH 7.9) and $40 \mathrm{ml}$ lysis buffer (50 mm-Tris, $10 \mathrm{~mm}$-EDTA, $1 \%$, w/v, SDS, pH 13.0) were added. The cell suspension was incubated at $65^{\circ} \mathrm{C}$ for 10 min and quickly chilled on ice. Cold $2 \mathrm{M}$-Tris/ $\mathrm{HCl}$ buffer $(\mathrm{pH} 7 \cdot 0 ; 12 \mathrm{ml})$ and cold $5 \mathrm{M}-\mathrm{NaCl}(18 \mathrm{ml})$ were added, and the lysate was incubated on ice for $3 \mathrm{~h}$. Cell wall debris and the bulk of chromosomal DNA were separated by centrifugation $(16800 \mathrm{~g}, 20 \mathrm{~min})$ and the pink, clear supernatant was extracted twice with phenol/chloroform ( $100 \mathrm{~g}$ phenol and $0.1 \mathrm{~g}$ hydroxyquinoline dissolved in $100 \mathrm{ml}$ chloroform saturated with $100 \mathrm{mM}-\mathrm{Tris} / \mathrm{HCl}, \mathrm{pH} 8 \cdot 0$ ) and once with chloroform. DNA was precipitated by adding $10 \%(\mathrm{v} / \mathrm{v})$ polyethylene glycol 6000 and $3 \%(\mathrm{w} / \mathrm{v})$ $\mathrm{NaCl}$. Plasmid DNA was further purified by centrifugation to equilibrium in $\mathrm{CsCl}$-ethidium bromide gradients (Maniatis et al., 1982).

Restriction endonucleases (Boehringer Mannheim and Pharmacia), T4 DNA ligase (Boehringer Mannheim) and bacterial alkaline phosphatase (Boehringer Mannheim) were used according to the manufacturer's recommendations. Digested total cellular and plasmid DNA were separated on horizontal $0.5-0.7 \%$ agarose gel with TAE buffer (Maniatis et al., 1982) at $2 \mathrm{~V} \mathrm{~cm}^{-1}$ for $16 \mathrm{~h}$ and stained in ethidium bromide $\left(5 \mathrm{mg} \mathrm{l}^{-1}\right)$. Gels were exposed on the top of a UV transilluminator $(\lambda=254 \mathrm{~nm})$ for $20 \mathrm{~min}$ and then soaked twice for $15 \mathrm{~min}$ in $0 \cdot 25 \mathrm{M}$ $\mathrm{HCl}$. DNA transfer to Hybond-N nylon membranes (Amersham) was done according to the method of Smith \& Summers (1980). Filter hybridization was done according to the manufacturer's directions for Hybond-N, using ${ }^{32}$ P-labelled, nick-translated DNA (Rigby et al., 1977).

Cosmid cloning. Bacteriophage $\lambda$ packaging extracts were prepared and in vitro packaging was performed according to Hohn (1973) as modified by Maniatis et al. (1982). The extracts were tested with $\lambda c 1857$ Sam7 DNA and $E$. coli LE392 as an indicator strain, and packaging efficiencies of $>10^{7}$ p.f.u. $(\mu \mathrm{g} \mathrm{DNA})^{-1}$ were achieved. Purified Methylobacterium sp. DM4 total cellular DNA (which was mixed with plasmid DNA from the same strain) was subjected to partial digestion with HindIII [ $300 \mu \mathrm{g} \mathrm{DNA} \mathrm{m}^{-1}, 0 \cdot 10 \mathrm{U}$ HindIII $(\mu \mathrm{g} \mathrm{DNA})^{-1} ; 20 \mathrm{~min}$ at $37^{\circ} \mathrm{C}$ according to Maniatis et al. (1982). DNA was size fractioned on a $0.5 \%$ agarose gel $(0.5 \mathrm{~V} \mathrm{~cm}-1,15 \mathrm{~h})$, and DNA fragments with a length of 15 to $28 \mathrm{~kb}$ were cut out of the gel with a sterilized razor blade. The fragments were electrophoretically separated from agarose in an electrophoretic chamber (Biotrap; Schleicher and Schuell) and precipitated with ethanol. The cosmid vector pVK100 was cut with HindIII and treated with alkaline

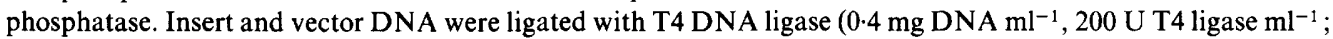
$16 \mathrm{~h}$ at $14{ }^{\circ} \mathrm{C} ; 3: 1$ ratio of vector to insert DNA). The ligated DNA was packaged and the phage particles adsorbed to E. coli $\mathrm{HB} 101$ as described by Maniatis et al. (1982). Typically, $10^{4} \mathrm{Km}^{\mathrm{s}} \mathrm{Tc}^{\mathrm{r}}$ colonies were obtained from $1 \mu \mathrm{g}$ ligated DNA. The HB101 clones were grown in freezing medium (Schleif \& Wensink, 1981) containing $\mathrm{Sm}$ and $\mathrm{Tc}$ and stored at $-70^{\circ} \mathrm{C}$.

Mobilization of cosmids and identification of recombinant clones. The ability of cosmids to complement $\mathrm{Dcm}^{-}$ mutants was tested by mobilizing the cosmids with the helper plasmid pRK2013 from E. coli HB101 into Methylobacterium sp. DM4-2cr. Multiples of 48 recombinant E. coli HB101 donors containing pVK 100 with 
inserts, arranged in a grid pattern on a master plate, were replica-plated onto a lawn of $E$. coli HB101(pRK2013) grown on nutrient agar. Matings were incubated at $37^{\circ} \mathrm{C}$ for $9 \mathrm{~h}$ and then replica-plated onto nutrient agar plates containing $\mathrm{Km}, \mathrm{Tc}$ and $\mathrm{Sm}$. After incubation at $37^{\circ} \mathrm{C}$ overnight these plates were patched onto a lawn of Methylobacterium sp. DM4-2cr grown on nutrient agar. After incubation at $30^{\circ} \mathrm{C}$ for $48 \mathrm{~h}$ the Methylobacterium plates were replica-plated onto methylamine agar $+\mathrm{Tc}+\mathrm{Sm}$ and onto DCM indicator agar $+\mathrm{Tc}+\mathrm{Sm}$. Clones growing on both methylamine and DCM were analysed for plasmid content and for DCM dehalogenase production by the antibody assay.

Rabbit antiserum against purified DCM dehalogenase of Hyphomicrobium sp. strain DM2 (Kohler-Staub et al., 1986) was used to detect clones of Methylobacterium sp. DM4 which produce DCM dehalogenase. Clones grown on agar plates were patched onto nitrocellulose filters (Schleicher and Schuell) and lysed by the method of Konheiser et al. (1984). Antiserum against the DCM dehalogenase (diluted $10^{3}$-fold) was used as a primary antibody and $10^{3}$-fold diluted peroxidase-labelled anti-rabbit goat IgG (Sigma) as the secondary antibody. The binding of the secondary antibody was made visible by developing the filters with 4-chloro-1-naphthol and $\mathrm{H}_{2} \mathrm{O}_{2}$ (Konheiser et al., 1984).

DCM dehalogenase assay. Cell-free extracts were prepared as previously described (Kohler-Staub et al., 1986) and protein concentrations were measured by the method of Bradford (1976). DCM dehalogenase activity in the extracts was determined by the enzyme assay described by Stucki et al., 1981).

\section{RESULTS}

\section{Plasmid patterns and the $\mathrm{Dcm}^{-}$phenotype}

Methylobacterium sp. DM4 is one of ten DCM-utilizing facultative methylotrophs we have analysed for plasmid content. These strains included Hyphomicrobium sp. DM2, in which we were unable to detect plasmid DNA, eight Pseudomonas sp., each containing a plasmid of approximately $120 \mathrm{~kb}$, and Methylobacterium sp. DM4, which exhibited the most complex plasmid pattern. Strain DM4 harboured plasmids pME1511, pME1512 and pME1513 with approximate sizes of $120 \mathrm{~kb}, 40 \mathrm{~kb}$ and $8 \mathrm{~kb}$, respectively (Fig. 1). Since the plasmid pattern and the DCM-utilization character of this bacterium were readily changed by a curing treatment, this organism was used to study whether or not the DCM-utilization genes are plasmid-encoded. Two representative DCM-degrading Pseudomonas strains, which were also examined, did not yield $\mathrm{Dcm}^{-}$mutants upon a variety of curing procedures.

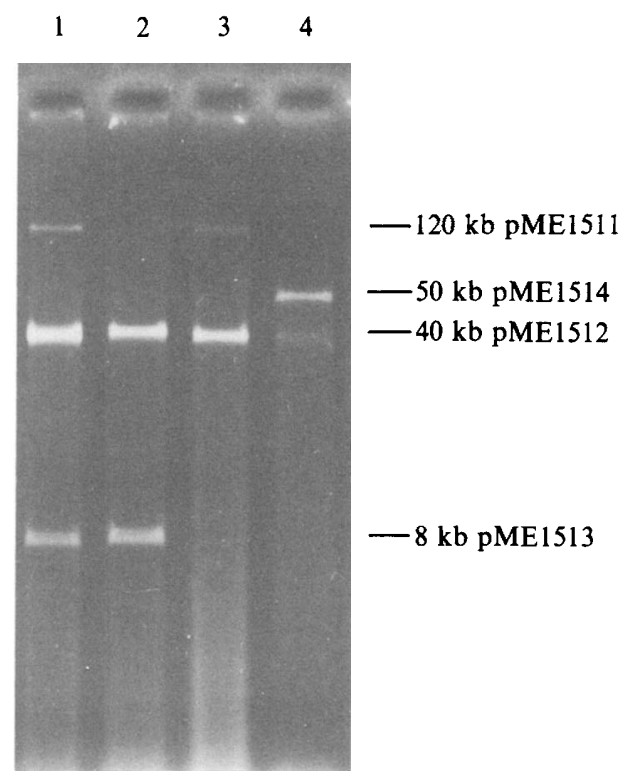

Fig. 1. Plasmid content of DCM-degrading positive $\left(\mathrm{Dcm}^{+}\right)$and negative $\left(\mathrm{Dcm}^{-}\right)$derivatives of Methylobacterium sp. strain DM4 after growth under curing conditions. Crude plasmid preparations were isolated as described in the text. Lanes: 1, DM4 $\left(\mathrm{Dcm}^{+}\right) ; 2, \mathrm{DM} 4-2 \mathrm{cr}\left(\mathrm{Dcm}^{-}\right) ; 3, \mathrm{DM} 4-161$ $\left(\mathrm{Dcm}^{+}\right)$; 4, DM4-161c $\left(\mathrm{Dcm}^{-}\right)$. 


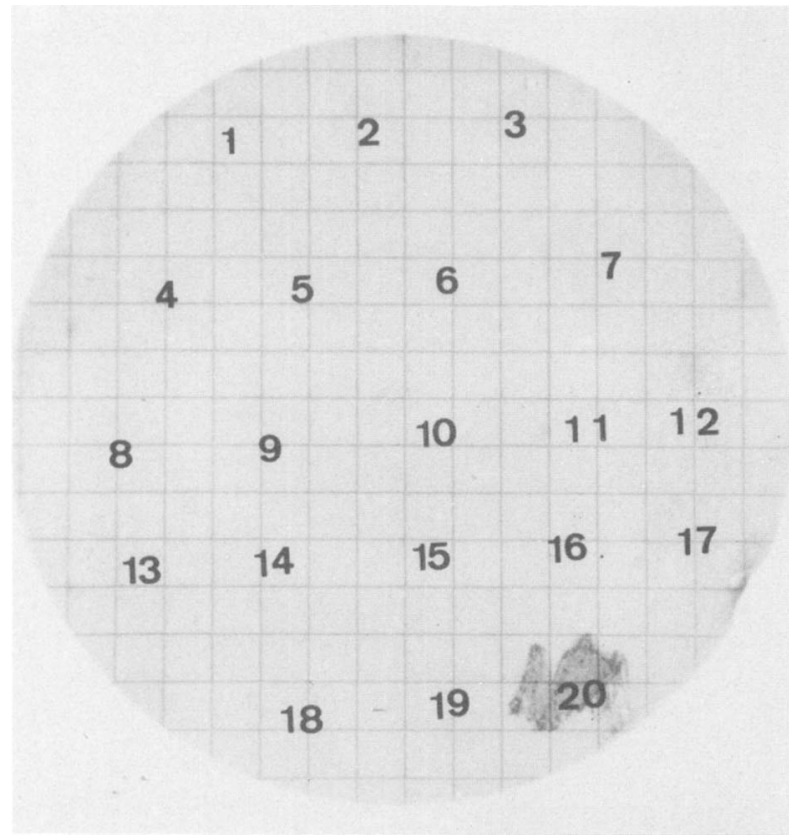

Fig. 2. DCM dehalogenase in different $\mathrm{Dcm}^{-}$mutants of Methylobacterium sp. strain DM4 as detected by the antibody assay. Cells were grown on methylamine agar plates, and the DCM dehalogenase protein was assayed as described in the text. Patches: $1-7, \mathrm{Dcm}^{-}$mutants derived from temperaturecuring on methanol (7, DM4-161 c);8-17, $\mathrm{Dcm}^{-}$mutants derived from temperature-curing on succinate (9. DM4-2cr); 18 and $19, \mathrm{Dcm}^{-}$mutants derived from mitomycin-C-curing on succinate; 20 , Methylobacterium sp. strain DM4 $\left(\mathrm{Dcm}^{+}\right)$.

Table 2. Loss of DCM-degrading activity by Methylobacterium sp. strain DM4 under plasmidcuring conditions

\begin{tabular}{|c|c|}
\hline \multicolumn{2}{|c|}{ Conditions } \\
\hline $\begin{array}{l}\text { Temperature } \\
\left({ }^{\circ} \mathrm{C}\right)\end{array}$ & Curing agent \\
\hline 30 & None \\
\hline 32 & None \\
\hline 30 & $\begin{array}{l}\text { Mitomycin C } \\
\left(1.0 \mathrm{mg} \mathrm{ml}^{-1}\right)\end{array}$ \\
\hline
\end{tabular}

\begin{tabular}{|c|c|}
\hline Succinate & Methanol \\
\hline $\begin{array}{l}<0.5 \\
22\end{array}$ & $\begin{array}{l}<0.5 \\
99\end{array}$ \\
\hline 4 & $<0.5$ \\
\hline
\end{tabular}

The data presented in Table 2 show that a high yield of $\mathrm{Dcm}^{-}$mutants was obtained upon growth of strain DM4 at the supra-optimal temperature of $32^{\circ} \mathrm{C}$. The loss of DCM dehalogenase in these mutants as well as in the $\mathrm{Dcm}^{-}$derivatives obtained by mitomycin $\mathrm{C}$ treatment appeared to be non-reversible (revertant frequency $<10^{-9}$ ). Using the antibody assay, which is more sensitive than the DCM dehalogenase enzyme assay, we examined whether the $\mathrm{Dcm}^{-}$ mutants still produced DCM dehalogenase protein. As evident from the example presented in Fig. 2 none of the $\mathrm{Dcm}^{-}$mutants produced antigenic material reacting with the antibody against DCM dehalogenase, whereas non-induced wild-type cells gave a strong signal. This suggests that the $\mathrm{Dcm}^{-}$mutants are not defective in the regulation of DCM dehalogenase synthesis or in DCM dehalogenase activity but have lost the structural gene of this enzyme. 


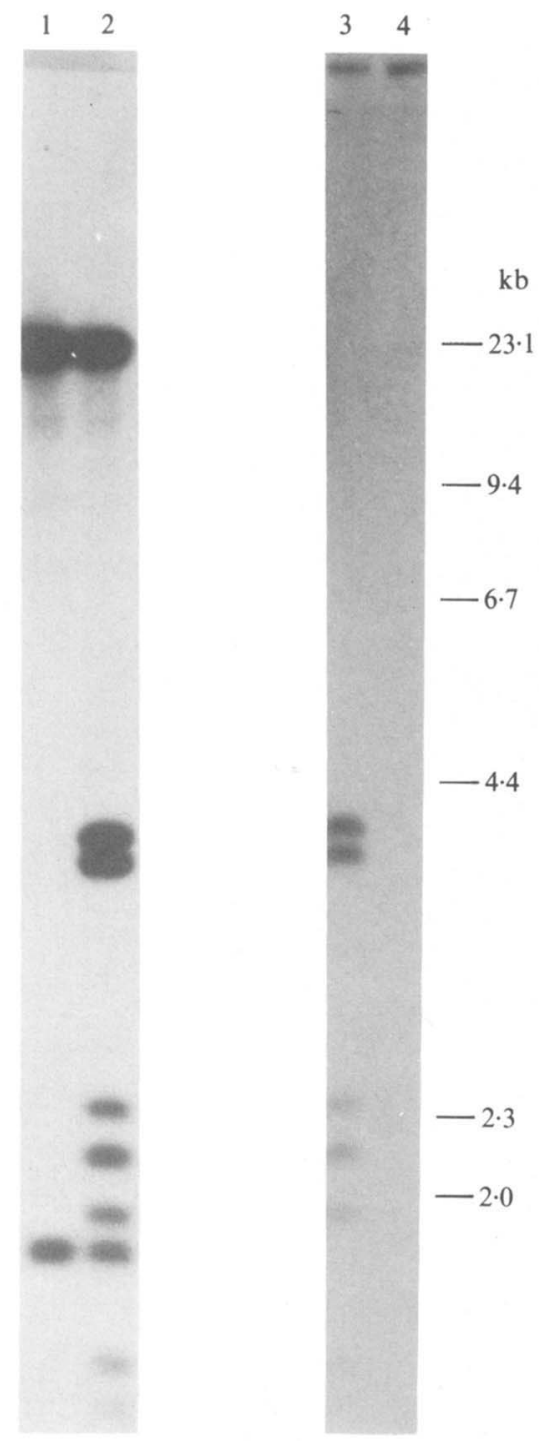

Fig. 3. Southern blot hybridization of ${ }^{32} \mathrm{P}-$ labelled pME1510 to HindIII/Sall-digested total cellular DNA from the wild-type DM4 and from the $\mathrm{Dcm}^{-}$ mutant DM4-2cr. Lanes: 1, pVK 100; 2, pME1510; 3, total cellular DNA from DM4; 4 , total cellular DNA from DM4-2cr. Lanes 1 and 2 contained $0.2 \mu \mathrm{g}$ DNA each and the film was exposed for $2 \mathrm{~h}$. Lanes 3 and 4 contained $1.0 \mu \mathrm{g}$ DNA at a film exposure time of $100 \mathrm{~h}$.

All of the $100 \mathrm{Dcm}^{-}$mutants examined for their plasmid content had lost plasmid pME1511. In most cases this loss was accompanied by the appearance of novel plasmid bands whose restriction patterns differed from the restriction profiles of the wild-type plasmids. The complex profiles observed were presumably due to DNA rearrangements. Eight $\mathrm{Dcm}^{+}$clones from populations which had undergone temperature curing were also analysed for their plasmid content and all of them contained an intact plasmid pME1511. A clear-cut change was observed in the $\mathrm{Dcm}^{-}$strains DM4-2c and its $\mathrm{Sm}^{r}$ derivative DM4-2cr (Fig. 1, Table 1); both had lost pME1511 and retained plasmids pME1512 and pME1513. Restriction analysis confirmed the identity of plasmids pME1512 and pME1513 of the wild-type with the corresponding plasmids contained in strain DM4-2cr (see Fig. $4 a$ ). The properties of strain DM4-2cr made it unlikely that pME1512 or pME1513 encode DCM-utilization genes. Strain DM4-161 is a Dcm ${ }^{+}$strain which had undergone temperature curing. It had lost pME1513 and retained plasmids pME1511 and pME1512 (Fig. 1), which demonstrated that pME1513 was not associated with the ability to grow on DCM. A second round of temperature curing with strain DM4-161 resulted in the 
Table 3. Expression of DCM dehalogenase in different hosts

\begin{tabular}{lcr}
\multicolumn{1}{c}{ Strain } & $\begin{array}{l}\text { Growth } \\
\text { conditions ... Non-induced* }\end{array}$ & $\begin{array}{c}\text { DCM dehalogenase } \\
\text { specific activity } \\
\text { [mkat (kg protein })^{-1} \text { Induced }\end{array}$ \\
Methylobacterium sp. DM4 & 0.12 & 1.87 \\
Methylobacterium sp. DM4-2cr & $<0.02$ & $<0.02$ \\
Methylobacterium sp. DM4-2cr(pME1510) & 0.15 & $2 \cdot 16$ \\
Methylobacterium sp. AM1r & $<0.02$ & $<0.02$ \\
Methylobacterium sp. AM1r(pME1510) & 0.12 & 0.63 \\
E. coli HB101(pVK100) & $<0.02$ & $<0.02$ \\
E. coli HB101(pME1510) & $<0.02$ & $<0.02$
\end{tabular}

\footnotetext{
* Methylobacterium strains were grown on minimal medium methanol; E. coli HB101 was grown on LB medium.

$\dagger$ Methylobacterium strains were grown on minimal medium with methanol and DCM as growth substrates; E. coli HB101 was grown on LB medium containing $2 \mathrm{mM}-\mathrm{DCM}$.
}

$\mathrm{Dcm}^{-}$mutant DM4-161c. It contained pME1514, a $50 \mathrm{~kb}$ plasmid which, by restriction analysis, was shown to be unrelated to the wild-type plasmid pME1511 (data not shown). Taken together, the curing experiments suggested that the DCM-utilization character was correlated with the possession of an intact plasmid pME1511. To examine this possibility in more detail the DCM-utilization genes were cloned.

\section{Cloning of a DNA fragment carrying the dcm region}

A total of $1200 \mathrm{Tc}^{\mathrm{r}}$ transductants of $E$. coli $\mathrm{HB} 101$, obtained with in-vitro-packaged DNA from a HindIII cosmid-library of Methylobacterium sp. DM4, were tested for the production of DCM dehalogenase by the antibody assay. The transductants were grown under inducing conditions on nutrient agar plates in a DCM-containing atmosphere, but none of them gave a positive signal. Fifty transductants were examined for their plasmid content: all of them contained recombinant cosmids having in common a $23 \mathrm{~kb}$ Hind III fragment (pVK 100) and one or more additional HindIII fragments corresponding to insert sizes in the range 15 to $26 \mathrm{~kb}$ with an average size of about $20 \mathrm{~kb}$. Of the 1200 transductants $98.6 \%$ were $\mathrm{Km}^{\mathrm{s}} \mathrm{Tc}^{\mathrm{r}}$ indicating inserted DNA in the $\mathrm{Km}$-resistance gene.

The cosmid clone bank was therefore mobilized with the help of plasmid pRK2013 into the $\mathrm{Dcm}^{-}$mutant DM4-2cr. Methylobacterium transconjugants growing on methylamine agar with $\mathrm{Sm}$ and $\mathrm{Tc}$ were selected and screened on DCM indicator-plates for the ability to degrade DCM. Among the 1200 transductants tested by this procedure one led to DCM-degrading transconjugants. The $44 \mathrm{~kb}$ plasmid of this strain was designated pME1510. Restriction enzyme analysis demonstrated that pME1510 extracted from E. coli HB101 and from Methylobacterium sp. DM4-2cr were identical. To determine whether the DNA insert of pME1510 was of Methylobacterium origin, total genomic DNA of this organism was digested with HindIII and SalI, and probed with nick-translated ${ }^{32}$ P-labelled pME1510 (Fig. 3). The recombinant cosmid pME1510 showed strong homology with DNA of the wild-type strain DM4, whereas it did not hybridize with DNA of the Dcm ${ }^{-}$mutant DM4-2cr. These observations demonstrate that the $21 \mathrm{~kb}$ HindIII fragment of pME1510 is of Methylobacterium DM4 origin and that this fragment is deleted from the genome of the $\mathrm{Dcm}^{-}$mutant DM4-2cr.

Plasmid pME1510 was transferred with the help of pRK2013 from E. coli to a number of facultative methyltrophs unable to grow on DCM and all probably belonging to the genus Methylobacterium (Green \& Bousfield, 1982). It conferred the ability to utilize DCM as the sole carbon and energy source to Methylobacterium organophilum XX, Protaminobacter ruber, Pseudomonas sp. M27, Methylobacterium sp. AM1 and Pseudomonas extorquens. With the exception of Methylobacterium organophilum XX, DCM degradation appeared to be stably maintained in these organisms. As shown in Table 3, pME1510 introduced in its 

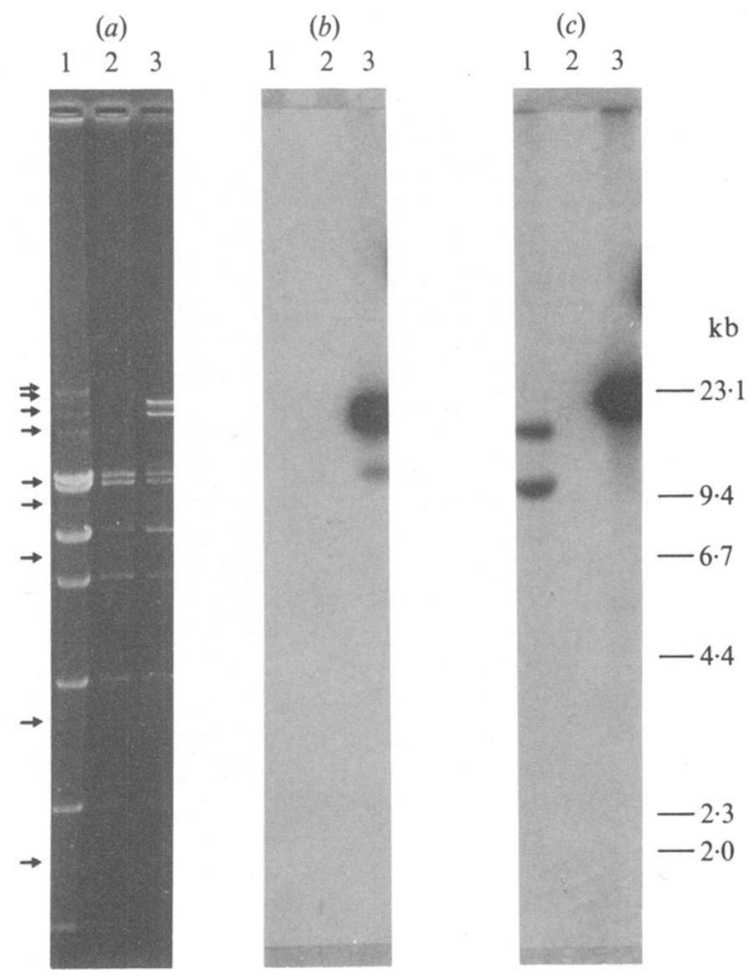

Fig. 4. Hybridization of ${ }^{32} \mathrm{P}$-labelled pME1510 encoding the DCM dehalogenase gene from Methylobacterium sp. strain DM4 to HindIII-digested plasmid DNA from DM4. (a) Ethidium-bromidestained gel; $(b, c)$ autoradiograms of the corresponding Southern blots after hybridization with ${ }^{32} \mathrm{P}$ labelled pME1510 $(b)$ and pME1515(c) as the probes. Lanes: 1, Plasmid DNA from the wild-type strain DM4; 2, plasmid DNA from the Dcm- mutant DM4-2cr; 3, plasmid DNA from the recombinant clone DM4-2cr(pME1510). Restriction fragments indicated by the small arrows (a) originated from pME1511.

Methylobacterium hosts conferred a DCM dehalogenase specific activity which was comparable to the activity present in the wild-type strain DM4. Since the dehalogenase activity encoded by pME1510 was induced by DCM in Methylobacterium sp. AM1r, both the DCM dehalogenase structural gene and a putative regulatory gene appear to be located on the cloned fragment. The absence of detectable dehalogenase activity in extracts of $E$. coli $\mathrm{HB} 101$ carrying pME1510 is in accordance with the results of the antibody assay and is probably due to the complete lack of expression of the DCM dehalogenase gene in E. coli.

After growing $E$. coli $\mathrm{HB} 101$ (pME1510) for 100 generations under non-selective conditions $61 \%$ of the population exhibited the Tc resistance conferred by the plasmid. When Methylobacterium DM4-2cr(pME1510) was grown for 30 generations on methanol without Tc $99 \%$ of the cells were $\mathrm{Tc}^{\mathrm{r}}$ and $\mathrm{Dcm}^{+}$.

\section{Chromosomal location of the dcm region}

The curing experiments described above indicated that the DCM-utilization genes might be encoded on plasmid pME1511. We examined this possibility by using pME1510 as a hybridization probe against the purified plasmid preparation from Methylobacterium sp. DM4. Since the efficiency of DNA transfer in the Southern hybridization procedure decreases with increasing size of DNA fragments (Wahl et al., 1979), it might be low for the entire $120 \mathrm{~kb}$ plasmid pME1511. We therefore used concentrated HindIII-restricted plasmid DNA of DM4 in the Southern hybridization experiment. As shown in Fig. 4(b) (lane 1) no hybridization signal corresponding to a $21 \mathrm{~kb}$ HindIII fragment could be detected. In a control experiment we used 
pME1515, a recombinant plasmid of pVK100, with a $7 \mathrm{~kb}$ SalI fragment of pME1511 as a hybridization probe. This probe produced definite signals at the position of pME1511 fragments (Fig. $4 c$ ). We thus conclude that the $\mathrm{dcm}$ genes are located neither on plasmid pME1511 nor on one of the two other cryptic plasmids of strain DM4, but must be carried on the chromosome or on a megaplasmid of Methylobacterium sp. DM4.

\section{DISCUSSION}

DCM is a xenobiotic compound which has been introduced into the environment in significant quantities by the industrial activities of the past forty years. In facultative methylotrophic bacteria utilizing this compound as a carbon source a high proportion of the total cellular protein consists of DCM dehalogenase, a catalytically inefficient, highly specific enzyme whose evolutionary origin is unknown (Kohler-Staub \& Leisinger, 1985). The numerous examples of plasmids coding for peripheral reactions in the catabolism of xenobiotics by soil bacteria (Haas, 1983) gave rise to the question whether the DCM-utilization character was also associated with a degradative plasmid. We did three types of experiments to examine this possibility in Methylobacterium sp. DM4.

Firstly, we investigated the correlation of the plasmid pattern with the $\mathrm{Dcm}^{-}$phenotype. Curing experiments showed that two of the three plasmids detected in the organism investigated were not associated with DCM utilization. However, loss of pME1511, the third and largest (120 $\mathrm{kb}$ ) plasmid, was paralleled by the loss of the $\mathrm{Dcm}^{+}$character. In a second series of experiments, not reported in the Results section, we attempted to demonstrate the concomitant transfer of DCM utilization and plasmid pME1511 from the wild-type strain to the cured derivative DM42cr. Transfer of the $\mathrm{Dcm}^{+}$phenotype by conjugation was not achieved. Despite the successful use of the broad-host-range plasmid R68.45 (Haas \& Holloway, 1978) for chromosome mobilization in Methylobacterium AM1 (Tatra \& Goodwin, 1983) we failed to transfer the Dcm ${ }^{+}$ character by R68.45 to strain DM4-2cr. R-Prime plasmids conferring the $\mathrm{Dcm}^{+}$phenotype could have been analysed with respect to the origin of their DNA. Since they were not found, these and other in vivo genetic experiments directed at determining the genomic location of the DCM-utilization genes have remained inconclusive. The goal of a third type of experiments was therefore to obtain direct evidence for the location of the $\mathrm{dcm}$ genes on either a plasmid or the chromosome. This was achieved by Southern hybridization experiments using a cloned $21 \mathrm{~kb}$ $H$ indIII fragment encompassing the $d c m$ genes as a probe. Since total genomic DNA of the wildtype strain DM4 hybridized with this probe, whereas a plasmid preparation from the same organism did not, the $\mathrm{dcm}$ genes must be encoded on the chromosome or on an extrachromosomal element that so far has remained undetected. No hybridization signal was obtained with total DNA from the cured derivative DM4-2cr.

As a consequence of this result we postulate that temperature curing and mitomycin $\mathrm{C}$ treatment not only lead to plasmid loss, but also induce the formation of a deletion larger than $21 \mathrm{~kb}$ and covering the $\mathrm{dcm}$ genes. Alternatively, curing might lead to the loss of an undetected megaplasmid.

An interesting question concerns the mechanism of transfer of the $\mathrm{dcm}$ genes between different methylotrophs. Since different isolates have been shown to contain closely similar if not identical DCM dehalogenases (Kohler-Staub et al., 1986), this process is assumed to occur readily in the environment. Transposition of the $\mathrm{dcm}$ region onto broad-host-range plasmids thus may be an essential step in spreading the $\mathrm{Dcm}^{+}$phenotype. Tentative evidence for the occurrence of transposons encoding haloalkanoic acid dehalogenase structural genes has been obtained in Moraxella (Kawasaki et al., 1981) and in Pseudomonas putida PP3 (Slater et al., 1985). The cloned $\mathrm{dcm}$ genes will be useful to investigate the evolution and distribution of the DCM utilization system in facultatively methylotrophic soil bacteria.

We wish to thank Alex Häusler for the construction of plasmid pME1515 and Dieter Haas for valuable discussions. The work described was supported in part by a grant from the Swiss Federal Institute of Technology, Zürich.

This paper is dedicated to Professor G. Semenza on the occasion of his sixtieth birthday. 


\section{REFERENCES}

Boyer, H. W. \& Roulland-Russoix, D. (1969). A complementation analysis of the restriction and modification of DNA in Escherichia coli. Journal of Molecular Biology 41, 459-472.

BRADFORD, M. M. (1976). A rapid and sensitive method for the quantitation of microgram quantities of protein utilizing the principle of protein-dye binding. Analytical Biochemistry 72, 248-254.

Brunner, W., Staub, D. \& Leisinger, T. (1980). Bacterial degradation of dichloromethane. Applied and Environmental Microbiology 40, 950-958.

Chesney, R. H., ScotT, J. R. \& VAPNeK, D. (1979). Integration of the plasmid prophages $\mathrm{Pl}$ and $\mathrm{P} 7$ into the chromosome of Escherichia coli. Journal of Molecular Biology 130, 161-173.

Figurski, D. H. \& HelinSKI, D. R. (1979). Replication of an orgin containing derivative of plasmid RK2 dependent on a plasmid function provided in trans. Proceedings of the National Academy of Sciences of the United States of America 76, 1648-1652.

GÄLLI, R. \& LEISINGER, T. (1985). Specialized bacterial strains for the removal of dichloromethane from industrial waste. Conservation and Recycling 8, 91100.

Green, P. N. \& Bousfield, I. J. (1982). A taxonomic study of some Gram-negative facultatively methylotrophic bacteria. Journal of General Microbiology 128, 623-638.

Green, P. N. \& Bousfield, I. J. (1983). Emendation of Methylobacterium Patt, Cole, and Hanson 1976; Methylobacterium rhodinum (Heumann 1962) comb. nov. corrig.; Methylobacterium radiotolerans (Ito and lizuka 1971) comb. nov. corrig.; and Methylobacterium mesophilicum (Austin and Goodfellow 1979) comb. nov. International Journal of Systematic Bacteriology 33, 875-877.

HAAS, D. (1983). Genetic aspects of biodegradation by pseudomonads. Experientia 38, 1199-1213.

HaAs, D. \& Holloway, B. W. (1978). Chromosome mobilization by the R plasmid R68.45: a tool in Pseudomonas genetics. Molecular and General Genetics 158, 223-237.

HOHN, B. (1973). In vitro packaging of $\lambda$ and cosmid DNA. Methods in Enzymology 68, 299-309.

Itoh, Y., Watson, J. M., HaAs, D. \& Leisinger, T. (1984). Genetic and molecular characterization of the Pseudomonas plasmid pVS1. Plasmid 11, 206220

KADO, C. J. \& LIU, S. T. (1981). Rapid procedure for detection and isolation of large and small plasmids. Journal of Bacteriology 145, 1365-1373.

KaWasaki, H., Tone, N. \& Tonomura, K. (1981). Plasmid-determined dehalogenation of haloacetates in Moraxella species. Agricultural and Biological Chemistry 45, 29-34.

Knauf, V. C. \& Nester, E. W. (1982). Wide host range cloning vectors: a cosmid clone bank of an Agrobacterium Ti plasmid. Plasmid 8, 45-54.
KohleR-STaub, D. \& Leisinger, T. (1985). Dichloromethane dehalogenase of Hyphomicrobium sp. strain DM2. Journal of Bacteriology 162, 676-681.

Kohler-Staub, D., Hartmans, S., Gälli, R. \& LEISINGER, T. (1986), Evidence for identical dichloromethane dehalogenases in different methylotrophic bacteria. Journal of General Microbiology 132 , 2837-2843.

Konheiser, U., Bollschweiler, C. \& Klein, A. (1984). Physical mapping of genes coding for two subunits of methyl-CoM reductase component $\mathrm{C}$ of Methanococcus voltae. Molecular and General Genetics 198, 146-152.

Lapat-Polasko, L. T., McCarty, P. L. \& Zehnder, A. J. B. (1984). Secondary substrate utilization of methylene chloride by an isolated strain of Pseudomonas sp. Applied and Environmental Microbiology 47, 825-830.

Maniatis, T., Fritsch, E. F. \& SambrooK, J. (1982). Molecular Cloning: a Laboratory Manual. Cold Spring Harbor, NY: Cold Spring Harbor Laboratory.

Peel, D. \& Quayle, J. R. (1961). Microbial growth on $\mathrm{Cl}$ compounds. 1. Isolation and characterization of Pseudomonas AM1. Biochemical Journal 81, 465-469.

Rigby, P. W. J., Dieckman, M., Rhodes, C. \& BerG, P. (1977). Labeling deoxyribonucleic acid to high specific activity in vitro by nick-translation with DNA polymerase I. Journal of Molecular Biology 113, 237-251.

Schleif, R. F. \& Wensink, P. C. (1981). Practical Methods in Molecular Biology, p. 201. New York: Springer Verlag.

Slater, J. H., Weightman, A. J. \& Hall, B. G. (1985). Dehalogenase genes of Pseudomonas putida PP3 on chromosomally located transposable elements. Molecular and Biological Evolution 2, 557-567.

Smith, G. E. \& Summers, M. D. (1980). The bidirectional transfer of DNA and RNA to nitrocellulose or diazobenzyloxymethyl-paper. Analytical Biochemistry 109, 123-129.

STUCKI, G., GÄlli, R., EBERSOLd, H.-R. \& LeISINGER, T. (1981). Dehalogenation of dichloromethane by cell extracts of Hyphomicrobium DM2. Archives of Microbiology 130, 366-371.

TATRA, P. K. \& Goodwin, P. M. (1983). R-Plasmidmediated chromosome mobilization in the facultative methylotroph Pseudomonas AM1. Journal of General Microbiology 129, 2629-2632.

Wahl, G. M., Stern, M. \& Stark, G. R. (1979). Efficient transfer of large DNA fragments from agarose gels to diazobenzyloxymethyl-paper and rapid hybridization by using dextransulfate. Proceedings of the National Academy of Sciences of the United States of America 76, 3683-3687. 